\title{
Effect of Resistant Starch and $\beta$-Glucan Combination on Oxidative Stability, Frying Performance, Microbial Count and Shelf Life of Prebiotic Sausage During Refrigerated Storage
}

\author{
Roghayeh Amini Sarteshnizi ${ }^{1}$, Hedayat Hosseini ${ }^{1}$, Nader Karimian Khosroshahi ${ }^{2}$, \\ Farzane Shahraz', Amin Mousavi Khaneghah ${ }^{3 *}$, Manije Kamran ${ }^{1}$, Rozita Komeili ${ }^{1}$ \\ and Emma Chiavaro ${ }^{4}$ \\ ${ }^{1}$ Food Sciences and Technology Department, National Nutrition and Food Technology Research Institute, \\ Faculty of Nutrition Sciences and Food Technology, Shahid Beheshti University of Medical Sciences, \\ 1981619573 Tehran, Iran \\ ${ }^{2}$ Department of Food and Drugs, Tabriz University of Medical Sciences, 5165665931 Tabriz, Iran \\ ${ }^{3}$ Department of Food Science, Faculty of Food Engineering, State University of Campinas (UNICAMP), Rua \\ Monteiro Lobato 80, 13083-862 Campinas, SP, Brazil \\ ${ }^{4}$ Department of Food and Drugs, University of Parma, Parco Area delle Scienze 27/A, \\ IT-43124 Parma, Italy
}

Received: August 19, 2017

Accepted: October 30, 2017

\begin{abstract}
Summary
This study aims to evaluate the performance of two types of prebiotic sausages formulated with resistant starch (RS) and $\beta$-glucan (BG) extract (in ratios of 2.22:1.33 and 2.75:1.88) during frying and chilled storage. The oxidative stability indices and microbial counts were determined. The incorporation of two types of prebiotic dietary fibre increased frying loss and oil absorption. However, the moisture content of prebiotic sausages after production was higher than of conventional sausages and it decreased significantly during storage. The use of sausage sample containing $2.22 \% \mathrm{RS}$ and $1.33 \% \mathrm{BG}$ as a recommended formulation can decrease fat oxidation of sausages during storage due to antioxidant properties of BG extract, but higher levels of RS and BG could not be used due to further increase in fat oxidation. Total viable count increased up to day 45 and decreased afterwards. The addition of BG extract improved the antioxidant properties of sausages. Additionally, the antimicrobial properties of BG and moisture reduction could inhibit microbial growth. Moreover, the addition of RS caused an increase in thiobarbituric acid and peroxide values.
\end{abstract}

Key words: prebiotic sausages, $\beta$-glucan extract, resistant starch, oxidation, microbial growth

"Corresponding authors: Phone: +982 122376 426; Fax: +982 122360 660; E-mail: hedayat@sbmu.ac.ir (Hosseini); Phone: +55(19) 3521 0091; Fax: +55(19) 3521 2153; E-mail: mousavi@fea.unicamp.br (Mousavi Khaneghah)

ORCID IDs: 0000-0003-4158-1326 (Sarteshnizi), 0000-0001-8301-4229 (Hosseini), 0000-0002-7556-5888 (Khosroshahi), 0000-0001-7234-8303 (Shahraz), 0000-0000-0001-5769-0004 (Mousavi Khaneghah), 0000-0003-1467-6741 (Kamran), 0000-0003-3722-2240 (Komeili), 0000-00024968-3709 (Chiavaro) 


\section{Introduction}

Functional food as one of the newly introduced topics in food science is a point of interest. It can be defined as 'whole foods and fortified, enriched, or enhanced foods that have a potentially beneficial effect on health when consumed as part of a varied diet on a regular basis, at effective levels' (1). The addition of functional ingredients such as prebiotics into food products is one of the common approaches for the development of functional foods (2). Among the prebiotics, incorporation of cereal-based ingredients such as $\beta$-glucan (BG) and resistant starch (RS) is highly ranked due to beneficial impacts as well as moderated formulation from the economic aspects $(3,4)$.

$\beta$-glucan is a soluble dietary fibre that mainly consists of the linear polysaccharide $(1 \rightarrow 3),(1 \rightarrow 4)-\beta$-D-glucan (3). It has been used as a fat replacer and functional ingredient in meat products (5). According to Thondre et al. (6), health benefits of BG extracts can be correlated with their polyphenol and antioxidant contents, depending on the method of preparation as well as purity.

Resistant starch is a non-digestible carbohydrate that can be partially or entirely fermented by gut microflora (7). Reducing faecal transit time, decreasing postprandial blood glucose, causing lipid metabolism and prebiotic function can be mentioned as some of the beneficial effects of RS addition (8). Using this approach, a new prebiotic sausage formulation was optimized by D-optimal mixture design. The best formulation contained $1.33 \%$ BG extract and $2.22 \%$ RS (9).

The stability assessment of a newly introduced food product regarding shelf life and growth of spoilage microorganisms is crucial (10). The storage time until the appearance of spoilage can be defined as 'shelf life' of meat and meat products. Namely, the defined maximum acceptable levels of the microbial growth, unacceptable off-odour/off-flavour or appearance are factors that are used to determine the point of spoilage (11). Unacceptable sensory characteristics may be related to some kind of deteriorations such as lipid oxidation, while both spoilage and foodborne diseases can be correlated with microbial growth (12). The addition of antioxidant compounds into fresh and processed meat could offer further delays in the development of off-flavours and, consequently prevent oxidative rancidity (13). Moreover, some of the natural antioxidants could exhibit antimicrobial activity against a wide range of microorganisms (12).

The current study was undertaken to investigate the effect of addition of resistant starch and $\beta$-glucan extract on the lipid oxidation and microbial counts during 60 days of refrigerated storage as well as frying performance of prebiotic sausages.

\section{Materials and Methods}

\section{Materials, sausage manufacturing and chilled storage}

The lean beef was supplied by Tehran Meat Products Company (Tehran, Iran). The oat $\beta$-glucan extract (mass fraction $34 \mathrm{~g} / 100 \mathrm{~g}$ ) was obtained from PromOat ${ }^{\mathrm{mw}}$ (Biovelop International AB, Kimstad, Sweden). Resistant starch
$\left(\mathrm{RS}_{2}\right)$, Hi-Maize 260, was purchased from National Starch Food Innovation (National Starch and Chemical Company, Bridgewater, NJ, USA). Hi-Maize 260 contained 60 $\mathrm{g}$ RS per $100 \mathrm{~g}$ of total starch based on total dietary fibre analysis.

The basic formulation consisted of (in \%): lean beef 55 with fat about 12.8, soybean oil 10, sodium chloride 1.5, sodium polyphosphate 0.35 , sodium nitrate 0.012 , ascorbic acid 0.02 , red pepper 0.2 , ginger 0.2 , savory 0.1 , garlic powder 0.2 and water 17.42, which altogether comprised $85 \%$ of the mixture, prepared using a cutter (Talsa K-15, Valencia, Spain) at $3500 \mathrm{rpm}$. A portion of about $4250 \mathrm{~g}$ of the basic formulation (85\%) was mixed with the experimental ingredients (BG, RS and wheat starch) as follows: $6 \%$ wheat starch (control); 2.22 RS, 1.33 BG and 2.46 $\%$ wheat starch (sausage 1); 2.75 RS, 1.88 BG and $1.38 \%$ wheat starch (sausage 2); $5 \%$ water and $4 \%$ wheat starch were added, and then the mixture was completely blended. The protocol for adding BG and RS to the mixture was adjusted according to D-optimal mixture design described by Amini Sarteshnizi et al. (9), where 13 formulations of prebiotic sausages were designed by Design-Expert software using the component ranges as follows: $1<\mathrm{BG}<3$, $2<\mathrm{RS}<3,1<$ wheat starch $<3$. After sensory and physicochemical evaluations, an optimum combination of BG extract and RS was obtained based on overall acceptability, cooking yield, frying loss and hardness. The formulation with the highest desirability $(0.878)$ contained $1.33 \%$ BG extract, $2.22 \% \mathrm{RS}$ and $2.46 \%$ wheat starch (9). This formulation and a formulation with a higher level of prebiotic ingredients (1.88 \% BG and $2.75 \%$ RS) and an acceptable desirability were selected for shelf life evaluation. After sausage production, the sausages were packed in vacuum packages and cooked in a steam oven at $80{ }^{\circ} \mathrm{C}$ for $60 \mathrm{~min}$ until reaching an internal temperature of $72-73^{\circ} \mathrm{C}$. Three replicates of each sample were produced. Sausage samples were stored at $(4 \pm 1)^{\circ} \mathrm{C}$ for 60 days. The proposed microbial and chemical analyses were carried out at storage intervals of $0,15,30,45$ and 60 days.

\section{Proximate composition and $\mathrm{pH}$}

Protein, moisture, ash, crude fibre and fat contents were determined in triplicate for each sample according to methods recommended by AOAC (14). Moisture was determined by hot air oven on day 0 . Fat and protein were determined by Soxhlet solvent extraction system (Soxtec ${ }^{\mathrm{TM}}$ Avanti 2050 Auto System; Foss Tecator AB, Höganäs, Sweden) and automatic Kjeldahl nitrogen analyzer (Kjeltec ${ }^{\odot}$ 2300 Analyzer Unit; Foss Analytical AB, Höganäs, Sweden), respectively. Crude fibre determination was carried out according to AOAC (14); briefly, samples were hydrolysed with $1.25 \% \mathrm{H}_{2} \mathrm{SO}_{4}$ solution for $30 \mathrm{~min}$ followed by basic hydrolysis with $1.25 \% \mathrm{NaOH}$ solution for $30 \mathrm{~min}$. The residues were filtered, washed with hot water, and dried at $105{ }^{\circ} \mathrm{C}$. The loss in mass during ashing at $550^{\circ} \mathrm{C}$ was calculated as the crude fibre content.

The triplicate determination of $\mathrm{pH}$ was carried out by homogenizing $10 \mathrm{~g}$ of each sample with distilled water in a sample to water ratio of 1:10. The homogenate was subjected to a pH test using a $\mathrm{pH}$ meter (inoLab $\mathrm{pH}$ Level 2; WTW, Germany) for 5 min after which the $\mathrm{pH}$ was read. 
Total calorific value was calculated according to the following equation:

$$
k=\left[\left(F_{\mathrm{P}} \cdot w_{\mathrm{P}}\right)+\left(F_{\mathrm{L}} \cdot w_{\mathrm{L}}\right)+\left(F_{\mathrm{C}} \cdot w_{\mathrm{C}}\right)+\left(F_{\mathrm{F}} \cdot w_{\mathrm{F}}\right)\right]
$$

where $k$ is the total calorific value $(\mathrm{kJ} / \mathrm{g})$ and $w_{\mathrm{p}}, w_{\mathrm{L}}, w_{\mathrm{C}}$ and $w_{\mathrm{F}}$ are the protein, lipid, carbohydrate and fibre content (in g/100 g) respectively. Calorific values of lipids $\left(F_{\mathrm{L}}\right)$, proteins $\left(F_{\mathrm{p}}\right)$, and carbohydrates $\left(F_{\mathrm{C}}\right)$ were estimated at 37.68 , 16.83 and $16.2 \mathrm{~kJ} / \mathrm{g}$, respectively (15). The calorific value of fibre $\left(F_{\mathrm{F}}\right)$, i.e. BG and RS, was determined to be $8.37 \mathrm{~kJ} / \mathrm{g}$ (16).

\section{Frying loss and oil absorption}

Frying loss was evaluated in triplicate according to the procedure described by Bengtsson et al. (17) with some modifications. Sliced sausages, $1 \mathrm{~cm}$ thick, was fried (DR5; Moulinex, Paris, France), and maintained at $174{ }^{\circ} \mathrm{C}$ for 2 min. The fat content of fried sausages was determined by a Soxhlet solvent extraction method (14) and compared with the fat content of sausages before frying.

\section{Lipid oxidation analysis}

The extent of lipid oxidation was assessed in triplicate by means of thiobarbituric acid reactive substance (TBARS) and peroxide values. The TBARS was evaluated according to the method explained by Ojagh et al. (18). A mass of $200 \mathrm{mg}$ of samples was added to a $25 \mathrm{~mL}$ volumetric flask, $1 \mathrm{~mL}$ of 1-butanol was used to dissolve the samples, and made to $25 \mathrm{~mL}$ by distilled water. Then, $5 \mathrm{~mL}$ of TBA reagent were added to $5 \mathrm{~mL}$ of the prepared mixtures in the test tubes and placed in the water bath $\left(95^{\circ} \mathrm{C}\right)$. After $120 \mathrm{~min}$ the samples were cooled and absorbance was measured at $530 \mathrm{~nm}$ using spectrophotometer (Cary 60; Agilent, Santa Clara, CA, USA). Water was used as the blank. TBARS was expressed in mg of malondialdehyde (MDA) per kg of sample. Peroxide value was measured according to the method developed by Egan et al. (19), and expressed in $\mathrm{mmol}$ of $\mathrm{O}_{2}$ per $\mathrm{kg}$ of the sample.

\section{Total volatile basic nitrogen}

Total volatile basic nitrogen (mg of TVB-N per $100 \mathrm{~g}$ of sausages) was determined according to the recommended procedure by Goulas and Kontominas (20) with some modifications. A mass of $10 \mathrm{~g}$ of minced sausages was mixed with $2 \mathrm{~g}$ of $\mathrm{MgO}$ (Sigma-Aldrich, St. Louis, MO, USA) and one drop of silicone (Merck, Darmstadt, Germany) used as antifoaming substance and then mixed with distilled water. The distillate was collected in a flask containing $3 \%$ aqueous solution of boric acid $(25 \mathrm{~mL})$ and a mixed indicator (dissolution of $0.1 \mathrm{~g}$ of methylene blue (Sigma-Aldrich) and $0.1 \mathrm{~g}$ methyl red (Sigma-Aldrich) to $100 \mathrm{~mL}$ of ethanol (Merck). and then titrated with $0.05 \mathrm{M}$ sulfuric acid solution (Merck).

\section{Microbiological analysis}

A mass of $10 \mathrm{~g}$ of each sample was aseptically weighed in sterile jars and mixed with $90 \mathrm{~mL}$ of sterile physiological saline solution $(0.85 \% \mathrm{NaCl})$. Aliquots $(1 \mathrm{~mL})$ of the sample were serially diluted in $9 \mathrm{~mL}$ of sterile physiological saline solution. Five-fold serial dilution was carried out twice for each sample. Each dilution was spread plated, in duplicate, on plate count agar (PCA; Merck) in order to count the aerobic bacteria at $35^{\circ} \mathrm{C}$ for $48 \mathrm{~h}$ and psychrophilic bacteria at $7{ }^{\circ} \mathrm{C}$ for 10 days (21). The Bacillus cereus was identified based on the ability to grow on mannitol-egg yolk-polymyxin (MYP) agar (Merck) incubated at $30{ }^{\circ} \mathrm{C}$ for 24 h (22). For Salmonella spp. detection peptone water (1\%; Merck) was used as a pre-enrichment medium, and the cultures were incubated at $37^{\circ} \mathrm{C}$ for $(18 \pm 2)$ h. Rappaport-Vassiliadis (RV) broth (Merck) was further used as an enrichment medium and incubated at $(42 \pm 2){ }^{\circ} \mathrm{C}$. After $22-24$ $\mathrm{h}$ a loopfull of RV broth was streaked on a brilliant green agar. The plates were incubated at $37{ }^{\circ} \mathrm{C}$ for $22-24 \mathrm{~h}$ for the detection of Salmonella colonies (23). The incubated (37 ${ }^{\circ} \mathrm{C}, 48 \mathrm{~h}$ ) sulfite polymyxin sulfadiazine (SPS) agar (Merck) was used for identification of Clostridium perfringens (24). Staphylococcus spp., S. aureus, coliforms, Escherichia coli, yeasts and moulds were identified through methods explained by Baumgart (25). Yeast extract-glucose-chloramphenicol (YGC) agar (Merck) incubated at $25^{\circ} \mathrm{C}$ for 5 days was used for enumeration of yeast and mould. Microbial counts were reported as colony forming units (CFU) per g of sausages. For Staphylococcus spp. identification, BairdParker agar plates (Merck) were incubated at $37{ }^{\circ} \mathrm{C}$ for 48 h. If the black, raised, glistening colonie s appeared, the coagulase formation test was carried out to identify the $S$. aureus strain. To identify coliforms, the violet red bile with glucose agar (VRBGA) was incubated at $30{ }^{\circ} \mathrm{C}$ for 48 $\mathrm{h}$. The observed round purple colonies on VRBGA were subjected to lauryl sulfate tryptose (LST) broth (Merck) containing Durham tubes at $35{ }^{\circ} \mathrm{C}$ for $48 \mathrm{~h}$ for gas production evaluation (colonies producing gas were counted as coliforms). Furthermore, gas production was tested by incubation in Escherichia coli (EC) broth (Merck) containing Durham tubes at $45^{\circ} \mathrm{C}$ for $48 \mathrm{~h}$. Indole formation test was carried out for samples with positive gas production to identify E. coli (E. coli colonies change the colour to purple-red).

\section{Statistical analysis}

The data were analyzed using SPSS v. 19 (SPSS Inc., Chicago, IL, USA) by one-way repeated-measures ANOVA test. Duncan's multiple range test was used to compare the mean values during treatment and least significant difference (LSD at $\mathrm{p}=0.05$ ) test was used to identify significant differences during storage time. Significance difference was defined at $\mathrm{p}<0.05$.

\section{Results and Discussion}

\section{Proximate composition and $\mathrm{pH}$ of prebiotic sausages}

As it was indicated in Table 1, partial replacement of starch by resistant starch (RS) and $\beta$-glucan (BG) significantly decreased the protein, fat, ash and carbohydrate contents of sausages and increased moisture content $(\mathrm{p}<0.001)$, which can be attributed to water-binding capacities of BG and RS. RS increased the moisture content of sausages due to high amylose content which has higher binding capacity than native starch (26). On the other hand, moisture content was decreased in control sausage 
Table 1. Composition, $\mathrm{pH}$ and calorific values $(k)$ of sausages

\begin{tabular}{|c|c|c|c|c|c|c|c|c|}
\hline \multirow{2}{*}{$\begin{array}{l}\text { Sausage } \\
\text { sample }\end{array}$} & \multirow{2}{*}{$w($ protein $) / \%$} & \multirow{2}{*}{$w($ fat $) / \%$} & \multirow{2}{*}{$w(\operatorname{ash}) / \%$} & \multirow{2}{*}{$w($ moisture $) / \%$} & \multirow{2}{*}{$\mathrm{pH}$} & \multicolumn{2}{|c|}{$w($ carbohydrate)/\% } & \multirow{2}{*}{ k/(kJ/g) } \\
\hline & & & & & & Total $^{1}$ & Crude fibre & \\
\hline Control & $(11.83 \pm 0.01)^{\mathrm{a}}$ & $(17.48 \pm 0.02)^{\mathrm{a}}$ & $(2.53 \pm 0.009)^{\mathrm{a}}$ & $(55.84 \pm 0.05)^{\mathrm{a}}$ & $(6.26 \pm 0.00)^{\mathrm{a}}$ & $(12.33 \pm 0.05)^{\mathrm{a}}$ & $(0.0 \pm 0.0)^{\mathrm{a}}$ & $(1057.58 \pm 0.42)^{\mathrm{a}}$ \\
\hline 1 & $(11.08 \pm 0.01)^{\mathrm{b}}$ & $(16.98 \pm 0.02)^{\mathrm{b}}$ & $(2.36 \pm 0.00)^{\mathrm{b}}$ & $(58.01 \pm 0.00)^{\mathrm{b}}$ & $(6.26 \pm 0.01)^{\mathrm{a}}$ & $(10.99 \pm 0.02)^{b}$ & $(0.57 \pm 0.01)^{\mathrm{b}}$ & $(1009.23 \pm 0.38)^{b}$ \\
\hline 2 & $(10.83 \pm 0.00)^{\mathrm{c}}$ & $(16.98 \pm 0.04)^{\mathrm{b}}$ & $(2.41 \pm 0.032)^{c}$ & $(58.2 \pm 0.1)^{c}$ & $(6.3 \pm 0.0)^{\mathrm{a}}$ & $(10.28 \pm 0.16)^{c}$ & $(1.280 \pm 0.01)^{\mathrm{c}}$ & $(996.88 \pm 1.25)^{c}$ \\
\hline p-value & $<0.001$ & $<0.001$ & $<0.001$ & $<0.001$ & NS & $<0.001$ & $<0.001$ & $<0.001$ \\
\hline
\end{tabular}

Values followed by the same lower case letter within the same column are not significantly different $(\mathrm{p}>0.05)$. NS=not significant

${ }^{1}$ Total carbohydrates without crude fibre

due to evaporation. Lower amount of total solids as the result of higher moisture content of enriched sausages resulted in lower protein, fat, ash and carbohydrate contents. Higher moisture content due to water-binding ability of BG in low-fat beef patties formulated with $13.45 \%$ BG was observed due to water-binding ability of BG (27). Morin et al. (28) demonstrated that low-fat, cooked sausages with $0.8 \%$ BG have an acceptable level of moisture content, while the highest drop after cooking was observed in sausages containing carboxymethyl cellulose (CMC). Additionally, a similar result was obtained by the addition of oat fibre and carrageenan to frankfurters (29).

The addition of BG and RS increased dietary fibre (DF) content of prepared sausages. The total dietary fibre content of BG and RS used as raw materials was about 34 and $60 \%$, respectively. Sausages formulated with $2.22 \%$ RS and $1.33 \%$ BG (sausage 1) and $2.8 \%$ RS and $1.9 \%$ BG (sausage 2) contained 0.57 and $1.28 \%$ fibre, respectively.

The $\mathrm{pH}$ value of prebiotic sausages containing $\mathrm{RS}$ and BG was not significantly different from control sausage ( $>>0.05$ ), indicating that BG and RS did not affect the $\mathrm{pH}$ of sausages.

Calorific value $(\mathrm{kJ} / \mathrm{g})$ of prebiotic sausages was significantly lower than of control, and this value was decreased by increasing the BG and RS mass fractions; the soluble dietary fibre has lower calorific value than digestible carbohydrates.

\section{Effect of prebiotic fibre on frying loss and oil absorption}

As it was demonstrated in Table 2, by incorporation of two types of prebiotic dietary fibre, the frying loss was increased significantly $(\mathrm{p}<0.05)$ and sausages with higher mass fractions of RS and BG had higher frying loss. Although the sausages with added prebiotics had lower fat content before frying, the higher fat content after frying was observed due to higher oil absorption than control $(p<0.05)$. Namely, sausages with higher moisture content had higher frying loss and higher oil absorption during frying. During frying, the decrease of moisture was recorded of $4.86 \%$ in control, and 7.91 and $8.46 \%$ in sausages containing 2.22 RS and 1.33 BG (sausage 1) and 2.75 RS and 1.88 BG (sausage 2), respectively (data not shown). Thus, $2.79 \%$ of the moisture was replaced by oil in control, and 4.03 and $4.24 \%$ in formulated sausages 1 and 2, respectively. RS and BG combination caused a significant increase in fat content during frying $(\mathrm{p}<0.05)$, while it was not significant in control sausage.

Since during frying inner moisture evaporates in form of steam and escapes through open channels and pores, the oil can enter the void left by the water (30). Therefore, the entrapped water in the matrix can be replaced by hot oil $\left(174{ }^{\circ} \mathrm{C}\right)$. In a previously conducted study (31), deep fat frying of pork meat resulted in a reduction of moisture and further increase of fat absorption. Moreover, the changes in moisture and fat contents showed a direct correlation with frying time (31).

\section{Effect of prebiotic fibre on moisture content during storage}

The changes (loss or gain) in moisture content can pose adverse effects on the food product by directly influencing its quality, textural properties and shelf life (32).

According to Fig. 1, initially prebiotic sausages had higher moisture content than control $(\mathrm{p}<0.001)$. During 60 days of refrigerated storage moisture content decreased in all samples. In the first 30 days, moisture content decreased only 0.8 and $1.4 \%$ in prebiotic sausages 1 and 2 , respectively. However, from day 30 to day 60 moisture content decreased by 5.58 and $5.83 \%$ in prebiotic sausages 1 and 2, respectively. At the end of storage, the moisture content of prebiotic sausages was lower than of control. Apart from that, higher moisture reduction was observed in sausages with higher dietary fibre mass fraction. Carballo et al. (33) reported that the gels created from polysaccharides could

Table 2. Frying loss and oil absorption of sausages

\begin{tabular}{cccc}
\hline $\begin{array}{c}\text { Sausage } \\
\text { sample }\end{array}$ & Frying loss & $\begin{array}{c}w \text { (fat before } \\
\text { frying) } / \%\end{array}$ & $\begin{array}{c}w \text { (fat after } \\
\text { frying)/\% }\end{array}$ \\
\hline Control & $(14.62 \pm 0.05)^{\mathrm{a}}$ & $(17.5 \pm 0.2)^{\mathrm{aA}}$ & $(20.3 \pm 0.5)^{\mathrm{aA}}$ \\
1 & $(17.5 \pm 0.1)^{\mathrm{b}}$ & $(16.98 \pm 0.02)^{\mathrm{bA}}$ & $(21.01 \pm 0.08)^{\mathrm{bB}}$ \\
2 & $(23.5 \pm 0.3)^{\mathrm{c}}$ & $(16.98 \pm 0.04)^{\mathrm{bA}}$ & $(21.2 \pm 0.2)^{\mathrm{cB}}$ \\
p-value & $<0.001$ & $<0.001$ & $<0.001$ \\
\hline
\end{tabular}

Values followed by the same lower case letter within the same column are not significantly different $(\mathrm{p}>0.05)$.

Values followed by the same capital letter do not show significant differences between fat content before and after frying $(\mathrm{p}>0.05)$ 


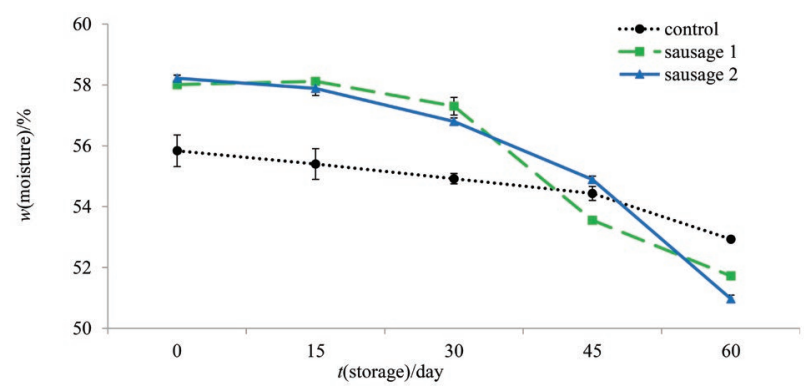

Fig. 1. Changes in moisture content of control and prebiotic sausages during storage at $4{ }^{\circ} \mathrm{C}$

form a denser and a stronger heat-induced protein matrix, leading to an increase in mass loss by reducing the binding of water. As it was mentioned before, BG, a soluble fibre, increases the amount of moisture held in a cooked meat protein system by physical entrapment of water. This free water could probably be released during storage. The resistant starch used in this study was $\mathrm{RS}_{2}$, which is high-amylose maize starch. During storage, intact or gelatinized amylose polymer is retrograded. This rearranging of amylose chain to crystalline forms could cause $\mathrm{RS}_{3}$ (retrograded amylose) formation $(34,35)$. It was also suggested that during storage, starch molecules could make complexes with protein or fat resulting in an increase in $\mathrm{RS}$ formation $(34,36)$, probably due to a decrease in their susceptibility to $\alpha$-amylase (37). Moreover, the gelatinization temperature range of $\mathrm{Hi}$ -Maize ${ }^{\circledast}$ starch is between 66 and $170{ }^{\circ} \mathrm{C}$ (35), while in the present study, the used temperature for cooking the sausages was higher $\left(80^{\circ} \mathrm{C}\right)$ than gelatinization temperature range. After preparation of sausages and during cooling and storage, the release of water and decrease in moisture content can probably be correlated with further retrogradation of incorporated starch. Similarly, the results of Banchathanakij and Suphantharika (38) showed that retrogradation and hardness of RS gel alone were greater than of the mixture of RS and various BGs. The retrogradation caused more syneresis and water release of RS gels, hence employing the different mass fractions of BGs could hinder long-term retrogradation of RS gel.

\section{Effect of prebiotic fibre on oxidative stability (TBA and peroxide values)}

The lipid oxidation can be considered one of the principal causes of quality deterioration in food, particularly in meat products (39). There was no significant difference in TBA values among sausages until day 30. As shown in Fig. 2a, sausage 1 had lower TBA value than sausage 2 and control after 30 days. No significant difference between fat oxidation in the samples until day 30 can be related to moisture content, since water has a protecting effect against lipid oxidation, which is related to solvation of the reacting sites with water that decrease their reactivity towards oxygen (40). Thus, greater changes in moisture content after day 30 might have caused the differences in fat oxidation among the samples. Incorporation of $1.33 \%$ BG extract in the combination with $2.22 \%$ RS decreased
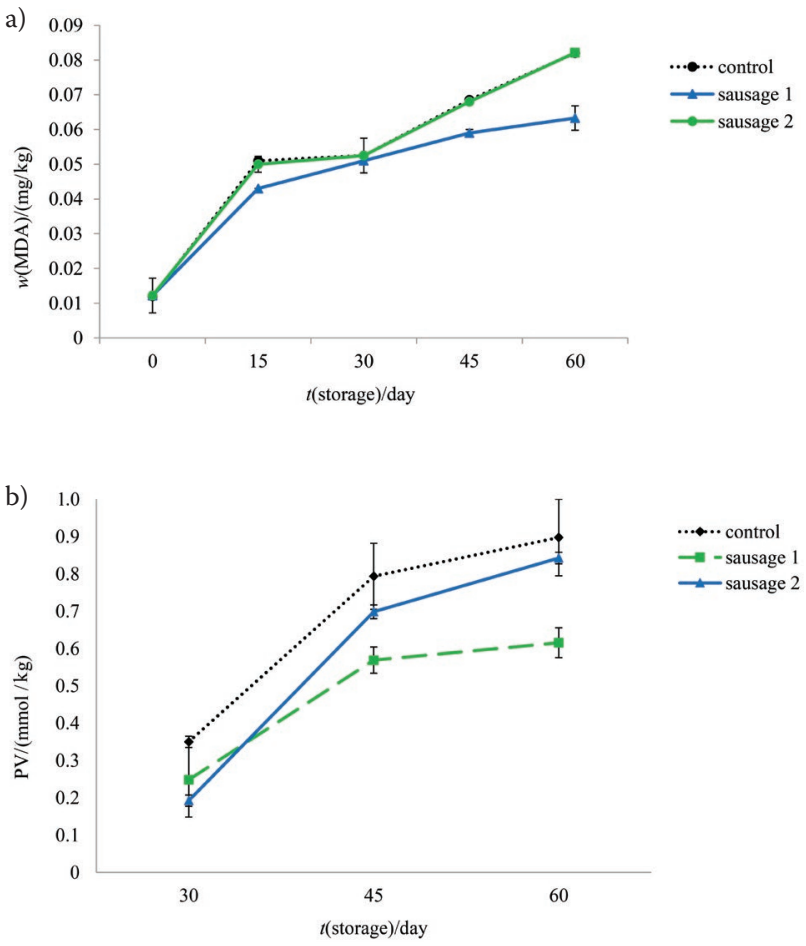

Fig. 2. Changes in: a) thiobarbituric acid (TBA) value (expressed as mass fraction of malondialdehyde (MDA) and b) peroxide value (PV) of control and prebiotic sausages during storage at $4{ }^{\circ} \mathrm{C}$

TBA value significantly $(\mathrm{p}<0.05)$, probably due to the antioxidant potential of BG extract. However, by increasing the mass fractions of RS and BG, TBA value increased in a similar trend to control sample.

As it was shown in Fig. 2b, the significantly higher peroxide values were recorded in control sample after 30 days of storage. By increasing storage time to 45 days, sausage 1 demonstrated significantly lower peroxide value than sausage 2 and control $(\mathrm{p}<0.05)$.

According to the TBA and peroxide values, it could be hypothesized that increasing the mass fraction of RS could increase fat oxidation. Omana et al. (41) documented antioxidant properties of BG in meat system. The results indicated that use of higher mass fractions of BG (including 46 $\%$ BG) as a salt replacer in high pressure processed chicken breast meat caused a decrease in TBA value. In addition, Haghshenas et al. (42) indicated that BG extract could decrease lipid peroxidation during storage of shrimp nuggets by inhibiting the formation of both primary and secondary oxidation products mainly due to the redox properties of phenolic compounds. In contrast, Higgins et al. (43) reported that RS could increase the fat oxidation of breakfast meal containing 2.7 and $5.4 \%$ RS in comparison with control. Similar result was reported by Nasrin and Anal (44). TBA value increased significantly in all groups under aerobic storage because lipid oxidation and volatile metabolites were enhanced in the presence of oxygen (45). After 60 days of storage, TBA value was lower than threshold value for the perception of rancidity by consumers. According to the results of Ockerman (46), meat products with MDA mass fractions higher than $1 \mathrm{mg} / \mathrm{kg}$ are subject to rancidity. 


\section{Effect of prebiotic fibre on TVB-N value}

As shown in Fig. 3, the initial TVB-N mass fractions of control, sausage 1, and sausage 2 samples were 19.4, 19.98 and $20.24 \mathrm{mg}$ per $100 \mathrm{~g}$, respectively. The TVB-N value increased gradually during whole storage period, except on the 15th day of storage, control showed lower TVB-N value than two treatments containing BG and RS. Between prebiotic sausages, samples with higher microbial counts showed higher TVB-N values, which can be attributed to amino acid decarboxylase activity of microorganisms and protein decomposition during storage. The trend of TVB-N changes did not comply precisely with the total viable count growth pattern.

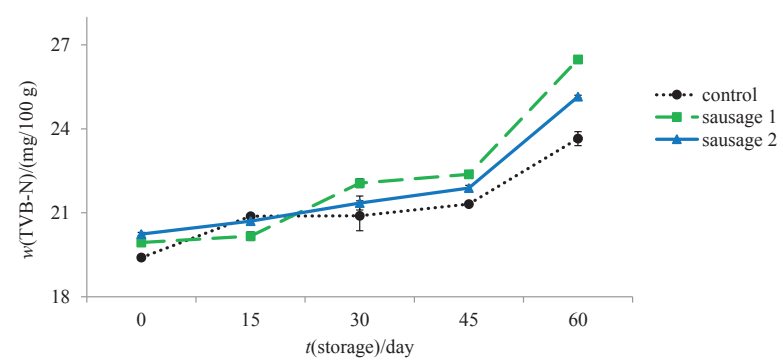

Fig. 3. Changes in total volatile basic nitrogen (TVB-N) mass fraction of control and prebiotic sausages during storage at $4{ }^{\circ} \mathrm{C}$

Increase of TVB-N value after decrease of total viable count can be associated with continuous decarboxylation activity of secreted decarboxylase enzymes, which are released in sausages simultaneously. Giménez et al. (47) suggested a value of $25 \mathrm{mg}$ of TVB-N per $100 \mathrm{~g}$ of fish as the highest acceptable level in the fish product. By considering this mass fraction as an acceptable level for sausages, on day 60 of storage both prebiotic sausages had higher TVB-N value than acceptable limit, but in the control sample it was below TVB-N cut-off.

\section{Effect of prebiotic fibre on microbial properties}

Due to enough heat treatment during production of cooked sausages based on good manufacturing practices (GMP) guidelines, no Clostridium perfringens, coliforms, E. coli, Staphylococcus spp., Salmonella spp. or Bacillus spp. were detected during storage. Coliforms are sensitive and were easily destroyed during heat treatment of frankfurters $(48)$. A significant $(\mathrm{p}<0.001)$ increase in the total viable count was observed in all samples up to day 45 and it decreased after that (Fig. 4a). After production of samples, the psychrophilic bacteria were counted in the highest count and it decreased dramatically afterwards (Fig. 4b). Mould increased up to day 15 and then was reduced significantly (Fig. 4c). Yeasts were not detected during storage. However, in 60 days of storage, microbial growth was lower than the limit established by the Iranian National Standard for Beef Sausages (49).

Reduction of microbial count during storage is probably due to the decrease in the moisture content of sausages, besides the presence of antimicrobial agents such as nitrite residue, phosphates and salt mass fraction. The ob-
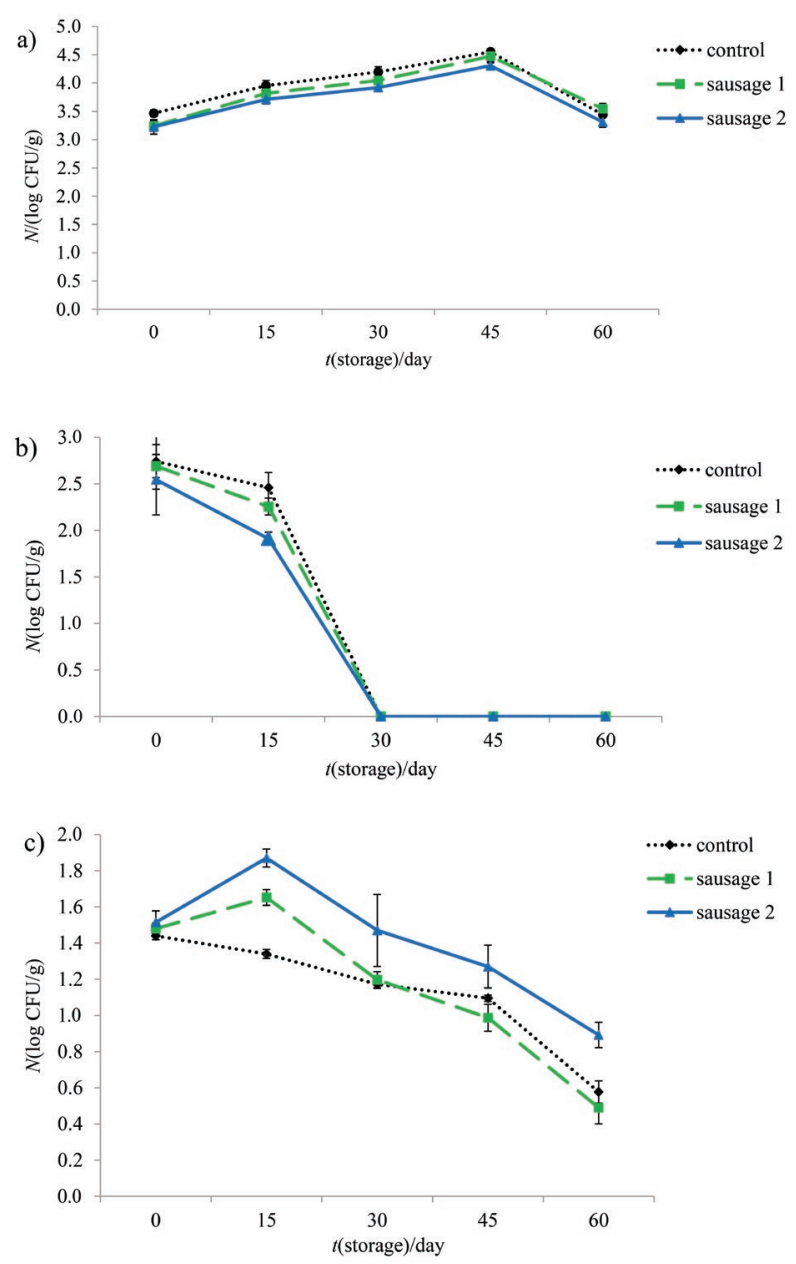

Fig. 4. Changes in: a) total viable count, b) psychrophilic count and c) mould count of control and prebiotic sausages during storage at $4{ }^{\circ} \mathrm{C}$

served decrease was consistent with the results obtained by Oksuz et al. (50), who reported that moisture content of dry sausages from African catfish decreased significantly during storage as well as a microbial count. It was concluded that moisture reduction has a positive effect on microbial reduction of sausages. Moisture reduction during storage might be related to drying, during which surface water evaporates and free interior water diffuses towards the periphery (51).

Study of the effect of orange dietary fibre on fermented sausages showed that during dry curing, the moisture content of sausages decreased and $a_{\mathrm{w}}$ reduction was in agreement with moisture reduction. Sausages with higher fibre mass fractions showed higher $a_{\mathrm{w}}$ reduction (52). Previously conducted investigations demonstrated that loss of free water slightly influences the decrease in $a_{\mathrm{w}}(53)$, and Gould (54) found that reduced $a_{\mathrm{w}}$ can inhibit the growth of microorganisms.

In a similar study, the effect of different binders on the shelf life of enrobed meat cutlets showed a significant increase in the mesophilic count up to the 10th day and decreased afterwards (55). Sausages with BG and RS showed lower total viable count than control during 60 days of storage. Higher psychrophilic count in 15 days of 
storage was recorded, and no significant difference was noted among the samples after 15 days. Lower microbial growth in prebiotic samples is probably due to the antimicrobial activity of BG related to the presence of bioactive compounds, especially polyphenols. Scientists have reported antimicrobial effects of oat BG against E. coli and Bacillus subtilis. According to the results of Shin et al. (56), underivatized oat $\beta$-glucan has up to around $35 \%$ inhibitory effects on E. coli and B. subtilis, depending on their concentration.

In another study, the effect of orange dietary fibre and oregano essential oil on the shelf life of bologna sausages was evaluated. The control product had higher total aerobic bacteria. Lower microbial growth in the samples containing orange dietary fibre and oregano essential oil was correlated with the antimicrobial activity of bioactive compounds, mainly polyphenols and terpenes, present in both fibre and essential oil (57).

\section{Conclusions}

The newly introduced prebiotic sausages had higher frying loss and oil absorption than conventional sausages. The addition of $2.22 \%$ resistant starch (RS) and $1.33 \%$ $\beta$-glucan (BG) successfully decreased fat oxidation of sausages during storage due to antioxidant properties of BG extract, but higher mass fractions of RS and BG increased fat oxidation. The antimicrobial properties of BG inhibited microbial growth and lower microbial count was observed during 60 days of storage when $2.22 \%$ RS and 1.33 \% BG were added. Prebiotic sausages had a maximum shelf life of 45 days. Longer storage time is not recommended because of high levels of total volatile basic nitrogen (TVB-N) and undesirable appearance of the product due to significant moisture reduction. Thus, incorporation of $2.22 \%$ RS and $1.33 \%$ BG mixture into sausage formulation could be a good strategy to reformulate traditional sausages to a healthier meat product.

\section{Acknowledgements}

Authors acknowledge the financial support of National Nutrition and Food Technology Research Institute (NNFTRI) of Iran. Also, we are thankful to Tehran Meat Product Company (Tehran, Iran) for their help in sausage manufacturing. Amin Mousavi Khaneghah likes to thank for the support of CNPq-TWAS Postgraduate Fellowship (grant no. 324027-4290).

\section{Conflict of interest}

Authors declare that they have no conflict of interest.

\section{References}

1. Hasler CM, Brown AC. Position of the American Dietetic Association: Functional foods. J Am Diet Assoc. 2009;109:735-46. https://doi.org/10.1016/j.jada.2009.02.023

2. Afshari R, Hosseini H, Khaksar R, Mohammadifar MA, Amiri Z, Komeili R, Mousavi Khaneghah A. Investigation of the effects of inulin and $\beta$-glucan on the physical and sensory properties of low-fat beef burgers containing vegetable oils: Optimisation of the formulation using D-optimal mixture design. Food Technol Biotechnol. 2015;53:436-45.

https://doi.org/10.17113/ftb.53.04.15.3980

3. Mitsou EK, Panopoulou N, Turunen K, Spiliotis V, Kyriacou A. Prebiotic potential of barley derived $\beta$-glucan at low intake levels: A randomised, double-blinded, placebo-controlled clinical study. Food Res Int. 2010;43:1086-92. https://doi.org/10.1016/j.foodres.2010.01.020

4. Rodríguez-Cabezas ME, Camuesco D, Arribas B, Garrido-Mesa N, Comalada M, Bailón E, et al. The combination of fructooligosaccharides and resistant starch shows prebiotic additive effects in rats. Clin Nutr. 2010;29:832-9.

https://doi.org/10.1016/j.clnu.2010.05.005

5. Amini Sarteshnizi R, Hosseini H, Mousavi Khaneghah A, Karimi, N. A review on application of hydrocolloids in meat and poultry products. Int Food Res J. 2015;22:872-87.

6. Thondre P, Ryan L, Henry CJK. Barley $\beta$-glucan extracts as rich sources of polyphenols and antioxidants. Food Chem. 2011;126:72-7.

https://doi.org/10.1016/j.foodchem.2010.10.074

7. Cummings JH, Beatty ER, Kingman SM, Bingham SA, Englyst HN. Digestion and physiological properties of resistant starch in the human large bowel. Br J Nutr. 1996;75:733-47. https://doi.org/10.1079/BJN19960177

8. Zi-Ni T, Rosma A, Napisah H, Karim AA, Liong MT. Characteristics of Metroxylon sagu resistant starch type III as prebiotic substance. J Food Sci. 2015;80:875-82.

https://doi.org/10.1111/1750-3841.12817

9. Amini Sarteshnizi R, Hosseini H, Bondarianzadeh D, Jiménez Colmenero F, Khaksar R. Optimization of prebiotic sausage formulation: Effect of using $\beta$-glucan and resistant starch by D-optimal mixture design approach. LWT - Food Sci Technol. 2015;62:704-10.

https://doi.org/10.1016/j.lwt.2014.05.014

10. Andrés SC, García ME, Zaritzky NE, Califano AN. Storage stability of low-fat chicken sausages. J Food Eng. 2006;72:311-9. https://doi.org/10.1016/j.jfoodeng.2004.08.043

11. Borch E, Kant-Muermans ML, Blixt Y. Bacterial spoilage of meat and cured meat products. Int J Food Microbiol. 1996;33:103-20. https://doi.org/10.1016/0168-1605(96)01135-X

12. Georgantelis D, Ambrosiadis I, Katikou P, Blekas G, Georgakis SA. Effect of rosemary extract, chitosan and $\alpha$-tocopherol on microbiological parameters and lipid oxidation of fresh pork sausages stored at $4{ }^{\circ} \mathrm{C}$. Meat Sci. 2007;76:172-81. https://doi.org/10.1016/j.meatsci.2006.10.026

13. Xiong YL, Decker EA, Robe GH, Moody WG. Gelation of crude myofibrillar protein isolated from beef heart under antioxidative conditions. J Food Sci. 1993;58:1241-4. https://doi.org/10.1111/j.1365-2621.1993.tb06156.x

14. Official Methods of Analysis of AOAC International. Rockville, MD, USA: AOAC international; 1995. pp. 1-23.

15. Watt BK, Mersil AL. Composition of foods - raw, processed, prepared. In: USDA Agriculture Handbook, vol. 8. Washington, DC, USA; USDA; 1975. pp. 346-66.

16. Cáceres E, García ML, Toro J, Selgas MD. The effect of fructooligosaccharides on the sensory characteristics of cooked sausages. Meat Sci. 2004;68:87-96. https://doi.org/10.1016/j.meatsci.2004.02.008

17. Bengtsson H, Montelius C, Tornberg E. Heat-treated and homogenised potato pulp suspensions as additives in low-fat sausages. Meat Sci. 2011;88:75-81. https://doi.org/10.1016/j.meatsci.2010.12.005

18. Ojagh SM, Rezaei M, Razavi SH, Hosseini SMH. Effect of chitosan coatings enriched with cinnamon oil on the quality of refrigerated rainbow trout. Food Chem. 2010;120:193-8.

https://doi.org/10.1016/j.foodchem.2009.10.006 
19. Egan H, Kirk RS, Sawyer R. Pearson's chemical analysis of foods. London, UK: Longman Group Ltd; 1991.

20. Goulas AE, Kontominas MG. Effect of salting and smokingmethod on the keeping quality of chub mackerel (Scomber japonicus): Biochemical and sensory attributes. Food Chem. 2005;93:511-20.

https://doi.org/10.1016/j.foodchem.2004.09.040

21. Viuda-Martos M, Ruiz-Navajas Y, Fernández-López JA, Pérez-Álvarez J. Effect of added citrus fibre and spice essential oils on quality characteristics and shelf-life of mortadella. Meat Sci. 2010;85:568-76

https://doi.org/10.1016/j.meatsci.2010.03.007

22. Güeven K, Mutlu MB, Avci Ö. Incidence and characterization of Bacillus cereus in meat and meat products consumed in Turkey. J Food Safety. 2006;26:30-40. https://doi.org/10.1111/j.1745-4565.2005.00031.x

23. Wiberg C, Norberg P. Comparison between a cultural procedure using Rappaport-Vassiliadis broth and motility enrichments on modified semisolid Rappaport-Vassiliadis medium for Salmonella detection from food and feed. Int J Food Microbiol. 1996;29:353-60. https://doi.org/10.1016/0168-1605(95)00074-7

24. Sachindra NM, Sakhare PZ, Yashoda KP, Rao DN. Microbial profile of buffalo sausage during processing and storage. Food Control. 2005;16:31-5. https://doi.org/10.1016/j.foodcont.2003.11.002

25. Baumgart J. Microbiological examination of food. Hamburg, Germany: Behr's Publishing House; 1999 (in German).

26. Zhiqiang L, Xiao-su Y, Yi F. Effect of bound water on thermal behaviors of native starch, amylose and amylopectin. Starch. 1999;51:406-10. https://doi.org/10.1002/(SICI)1521379X(199912)51:11/12<406::AID-STAR406>3.0.CO;2-K

27. Piñero MP, Parra K, Huerta-Leidenz N, de Moreno LA, Ferrer M, Araujo S, Barboza Y. Effect of oat's soluble fibre ( $\beta$-glucan) as a fat replacer on physical, chemical, microbiological and sensory properties of low-fat beef patties. Meat Sci. 2008;80:675-80. https://doi.org/10.1016/j.meatsci.2008.03.006

28. Morin LA, Temelli F, McMullen L. Physical and sensory characteristics of reduced-fat breakfast sausages formulated with barley $\beta$-glucan. J Food Sci. 2002;67:2391-6. https://doi.org/10.1111/j.1365-2621.2002.tb09559.x

29. Cofrades S, Hughes E, Troy DJ. Effects of oat fibre and carrageenan on the texture of frankfurters formulated with low and high fat. Eur Food Res Technol. 2000;211:19-26. https://doi.org/10.1007/s002170050583

30. Pinthus EJ, Weinberg P, Saguy IS. Criterion for oil uptake during deep-fat frying. J Food Sci. 1993;58:204-5. https://doi.org/10.1111/j.1365-2621.1993.tb03245.x

31. Sosa-Morales ME, Orzuna-Espíritu R, Vélez-Ruiz JF. Mass, thermal and quality aspects of deep-fat frying of pork meat. J Food Eng. 2006;77:731-8. https://doi.org/10.1016/j.jfoodeng.2005.07.033

32. Esse R, Saari A. Shelf-life and moisture management. In: Steele $\mathrm{R}$, editor. Understanding and measuring the shelf-life of food. Cambridge, UK: Woodhead Publishing Ltd; 2004. pp. 24-41. https://doi.org/10.1533/9781855739024.1.24

33. Carballo J, Fernandez P, Barreto G, Solas MT, Jiménez Colmenero F. Morphology and texture of bologna sausage as related to content of fat, starch and egg white. J Food Sci. 1996;61:652-65. https://doi.org/10.1111/j.1365-2621.1996.tb13179.x

34. Namratha J, Asna U, Prasad NN. Effect of storage on resistant starch content of processed ready-to-eat-foods. Food Chem. 2002;79:395-400

https://doi.org/10.1016/S0308-8146(02)00210-8

35. Whistler RL, BeMiller JN. Starch. In: Whistler RL, BeMiller JN, editors. Carbohydrate chemistry for food scientists. St. Paul, MN, USA: Eagan Press; 1997.
36. Niba LL. Resistant starch: a potential functional food ingredient. Nutr Food Sci. 2002;32:62-7. https://doi.org/10.1108/00346650210416985

37. Aigster A, Duncan SE, Conforti FD, Barbeau WE. Physicochemical properties and sensory attributes of resistant starch-supplemented granola bars and cereals. LWT - Food Sci Technol. 2011;44:2159-65. https://doi.org/10.1016/j.lwt.2011.07.018

38. Banchathanakij R, Suphantharika M. Effect of different $\beta$-glucans on the gelatinisation and retrogradation of rice starch. Food Chem. 2009;114:5-14. https://doi.org/10.1016/j.foodchem.2008.09.016

39. Morrissey PA, Sheehy PJA, Galvin K, Kerry JP, Buckley DJ. Lipid stability in meat and meat products. Meat Sci. 1998;49:57-86. https://doi.org/10.1016/S0309-1740(98)90039-0

40. Bailey ME. Maillard reactions and meat flavor development. In: Shahidi F, editor. Flavor of meat, meat products and seafood. London, UK: Blackie Academic and Professional; 1998.

41. Omana DA, Plastow G, Betti M. Effect of different ingredients on color and oxidative characteristics of high pressure processed chicken breast meat with special emphasis on use of $\beta$-glucan as a partial salt replacer. Innov Food Sci Emerg Technol. 2011;12:244-54. https://doi.org/10.1016/j.ifset.2011.04.007

42. Haghshenas M, Hosseini H, Nayebzadeh K, Kakesh BS, Mahmoudzadeh M, Fonood RK. Effect of beta glucan and carboxymethyl cellulose on lipid oxidation and fatty acid composition of pre-cooked shrimp nugget during storage. LWT - Food Sci Technol. 2015;62:1192-7. https://doi.org/10.1016/j.lwt.2015.01.042

43. Higgins JA, Higbee DR, Donahoo WT, Brown IL, Bell ML, Bessesen DH. Resistant starch consumption promotes lipid oxidation. Nutr Metab. 2004;1:8. https://doi.org/10.1186/1743-7075-1-8

44. Nasrin TAA, Anal AK. Resistant starch III from culled banana and its functional properties in fish oil emulsion. Food Hydrocolloid. 2014;35:403-9. https://doi.org/10.1016/j.foodhyd.2013.06.019

45. Bullock KB, Huffman DL, Egbert WR, Mikel WB, Bradford DD, Jones WR. Storage stability of low-fat ground beef made with lower value cuts of beef. J Food Sci. 1994;59:6-9. https://doi.org/10.1111/j.1365-2621.1994.tb06884.x

46. Ockerman HW. Quality control of post-mortem muscle and tissue. Columbus, OH, USA: The Ohio State University; 1995.

47. Giménez B, Roncalés P, Beltrán JA. Modified atmosphere packaging of filleted rainbow trout. J Sci Food Agric. 2002;82:1154-9. https://doi.org/10.1002/jsfa.1136

48. Hung SC, Zayas JF. Sensory, chemical and bacteriological stability of frankfurters containing milk proteins and corn germ protein flour. J Food Proc Pres. 1991;15:413-31. https://doi.org/10.1111/j.1745-4549.1991.tb00185.x

49. NO. 2303. Iranian national standard for beef sausages, Tehran, Iran: Institute of standard and industrial research; 2011 (in Persian).

50. Oksuz A, Akdemir Evrendilek G, Calis MS, Ozeren A. Production of a dry sausage from African catfish (Clarias gariepinus, Burchell, 1822): microbial, chemical and sensory evaluations. Int J Food Sci Technol. 2008;43:166-72. https://doi.org/10.1111/j.1365-2621.2006.01418.x

51. Pérez-Alvarez JA, Sayas-Barberá ME, Fernández-López J, Aranda-Catalá V. Physicochemical characteristics of Spanish-type dry-cured sausage. Food Res Int. 1999;32:599-607. https://doi.org/10.1016/S0963-9969(99)00104-0

52. Fernández-López J, Sendra E, Sayas-Barberá E, Navarro C, Pérez-Alvarez JA. Physico-chemical and microbiological profiles of 'salchichón' (Spanish dry-fermented sausage) enriched with 
orange fiber. Meat Sci. 2008;80:410-7.

https://doi.org/10.1016/j.meatsci.2008.01.010

53. Roig-Sagués AX, Hernández-Herrero MM, López-Sabater EI, Rodríguez-Jerez JJ, Mora-Ventura MT. Microbiological events during the elaboration of 'fuet', a Spanish ripened sausage. Relationships between the development of histidine- and tyrosine-decarboxylase-containing bacteria and $\mathrm{pH}$ and water activity. Eur Food Res Technol. 1999;209:108-12.

https://doi.org/10.1007/s002170050467

54. Gould G. Present state of knowledge of $\mathrm{a}_{\mathrm{w}}$ effects on microorganisms. In: Simatos D, Multon, JL, editors. Properties of water in foods. NATO ASI series (Series E: Applied sciences), vol. 90. Dordrecht, The Netherlands: Springer; 1985.

https://doi.org/10.1007/978-94-009-5103-7_14
55. Ahamed ME, Anjaneyulu ASR, Sathu T, Thomas R, Kondaiah N. Effect of different binders on the quality of enrobed buffalo meat cutlets and their shelf life at refrigeration storage $\left(4 \pm 1^{\circ} \mathrm{C}\right)$. Meat Sci. 2007;75:451-9. https://doi.org/10.1016/j.meatsci.2006.08.008

56. Shin MS, Lee S, Lee KY, Lee HG. Structural and biological characterization of aminated-derivatized oat $\beta$-glucan. J Agric Food Chem. 2005;53:5554-8.

https://doi.org/10.1021/jf050273j

57. Viuda-Martos M, Ruiz-Navajas Y, Fernández-López J, Pérez-Álvarez JA. Effect of orange dietary fibre, oregano essential oil and packaging conditions on shelf-life of bologna sausages. Food Control. 2010;21:436-43.

https://doi.org/10.1016/j.foodcont.2009.07.004 